\title{
WINNICOTT'S STYLE AND ITS IMPLICATIONS: A STUDY ON AUTHORIZATION, AUTHENTICITY AND INFLUENCE IN PSYCHOANALYSIS
}

Wilson de Albuquerque Cavalcanti Franco and Luís Cláudio Figueiredo

Wilson de Albuquerque
Cavalcanti Franco
Universidade
de São Paulo
(USP), Instituto
de Psicologia, São
Paulo/SP, Brasil.
Luís Cláudio Figueiredo
Universidade
de São Paulo
(USP), Instituto
de Psicologia, São
Paulo/SP, Brasil.
Pontifícia
Universidade
Católica de São
Paulo (PUC-SP),
Programa de
Pós-Graduação em
Psicologia Clínica,
São Paulo/SP, Brasil.

ABSTRACT: The article focuses on the consequences of Winnicott's style for his work and for the psychoanalysis inspired by his work. Within this framework, the article discusses possibilities and deadlocks for an appropriation of Winnicott's work and the complex relation between his work and dogmatism, formation, innovation and filiation.

Keywords:psychoanalysis; psychoanalytical theory; Winnicott, Donald Woods; authorship.

RESUMO: O estilo de Winnicott e suas implicações: um estudo sobre autenticidade, filiação e influência em psicanálise. $O$ artigo se propõe a abordar as consequências do estilo de Winnicott para sua produçãoe para a psicanálise inspirada por seu trabalho. Discute-se, nesse enquadre, as possibilidade e entraves para uma apropriação do trabalho de Winnicott e a complexa relação de sua obra com o dogmatismo, a formação e a inovação.

Palavras-chave: psicanálise; teoria psicanalítica; Winnicott, Donald Woods; autoria.

DOI - http://dx.doi.org/10.1590/S1516-14982016002012 


\section{INTRODUCTION}

This article aims at approaching the style of Winnicott - actually it intends to address the intimate relationship between the style, the theorizing and how Winnicott's legacy was incorporated by psychoanalysis after him. Such proposal meets one of the most cited and commented passages of Winnicott — a passage that deals with his style and method, and not with his theoretical conceptions (at least not directly); we refer to the beginning of his famous Primitive Emotional Development, in which he states:

I shall not first give an historical survey and show the development of my ideas from the theories of others, because my mind doesn't work that way. What happens is that I gather this and that, here and there, settle down to clinical experience, form my own theories and then, last of all, interest myself in looking to see where I stole what. Perhaps this is as good a method as any. (WINNICOTT, 1945/2000 a, p. 218).

It does not seem a coincidence that Winnicott has set up for himself such a methodology, nor that he has considered it worth of his interest professing it openly in the introduction of his text; in fact, it seems to us an overwhelming demonstration of consistency for the man who some years later would postulate the concepts of objects and of transitional phenomena (WINNICOTT, 1971/2010). Winnicott's position in 1945 shows us how the clinical thinking and the author's innovative theorizing closely relate with his positioning before peers and the general public and, even more, as reflected in the configuration of a style?

This article is not meant to solve a problem - in fact it questions the role of circumscription attempts regarding the uniqueness of Winnicott ${ }^{2}$, theorization, arguing the importance of the problems and their non-resolution. It may be necessary that the importance of Winnicott, as a master, is recognized without the appeal to the statutory and to the sanctuary, in accordance with the radicalism of his propositions; if that were to happen, it certainly would not be at the expense of the figure, but in the name of the full seizure of the power of his propositions within psychoanalysis, as a practice, as discourses and as an institution.

The present text will publish some anecdotes concerning Winnicott's biography — not as biographer preciousness, nor for "validation" of hypotheses, but with the proposal of moving the image constructed of Winnicott by the reading that historically has been made of his work; that's because we assume that the

\footnotetext{
${ }^{1}$ A detailed demonstration of this imbrication, was presented using exactly the text Primitive Emotional Development, by the American psychoanalyst Thomas Ogden in his article Reading Winnicott (OGDEN, 2001).

${ }^{2}$ As it happens in "winnicottism schools" and in the work of some other authors who suggest and militate for a wittcottian orthodoxy (whatever it is).
} 
works of famous authors in psychoanalysis configure a kind of imago, associated with their work, limiting the possibility of creative thinking and re-creation of the work, of the texts and of their creative directness ${ }^{3}$. These anecdotes, therefore, have the main role to promote the complexification of that imago, by the attachment of foreign elements to the prevailing stereotype in Winnicott's imago composition.

\section{SCENE 1 - DWW ON DWW}

In January 1967, Winnicott was invited to give a lecture to a group of British therapists called Club 1952; this group wanted him to explain the relationship of his work with the thought of other psychoanalysts - and from this fact we can observe that at that time this was already an issue...

Winnicott, as we are informed by the organizers of the collection Psychoanalytic Explorations (where a transcript of this lecture is included), decided to name the meeting with the title "DWW on DWW" - DWW being, obviously, the acronym for his full name, Donald Woods Winnicott (WINNICOTT, SHEPHERD and DAVIS, 2007).

Why did he do it? The group invited him to talk about the relationship of his thinking with that of other psychoanalysts and, in response, Winnicott proposes a title that could perfectly be a short circuit: he's talking about himself, or the relationship of his presence in the group with his work, or any other thing that's worth it.

One might think that Winnicott refuses to talk about other authors. Or we could think that he understands that something is something else: that to talk about the relationship of his thinking with that of other psychoanalysts is talking about himself. As if he said that it's impossible to talk about his relationship with other psychoanalysts "from outside", because he could only access it from his own thinking; as if he said that

It seems impossible to talk about the individual without talking about the mother because the mother or the person in her place is a subjective object - in other words, it was not objectively understood - and therefore, the way in which the mother behaves really is part of the baby (WINNICOTT, 1967/2007, p. 441).

The hypothesis, in this case, would be: are the authors in whom Winnicott is inspired "subjective objects" for him?

\footnotetext{
${ }^{3}$ For more details on this matter, I would refer the reader to my Master's dissertation: authorization and influence anguish in Winnicott (FRANCO, 2012).
} 
In front of that Club 1952 audience, Winnicott feels, in a way, sorry for not having done the associations of his thinking with that of other psychoanalysts. Early in his speech he says:

As time went by, I realized more and more how much I had lost because I didn't make the appropriate association of my work with the work of others. This [...] meant that what I said was isolated and people had to take a lot of work to get to it. It turns out that that's my temper and it is a major flaw (WINNICOTT, 1967/2007, p. 437).

A few things are clear in this passage: the first one is that he already knew beforehand that he didn't properly associate his work with that of others; the second is that he was able to realize that this had a cost, and that he could realize that cost little by little - and this cost to him is the isolation of his work and the work that people have to submit to "get" to him; the third one is that he considers all this a result of a "failure" due to his "temper".

We believe that this passage allows us to revisit the opening quote of Primitive Emotional Development ("where I stole what...") in one important aspect: in that passage, he says that his method of "stealing" here and there the ideas that inspire him is probably a method "as good as any other" — that's what he states in 1945. We see, however, that in 1967 he understands this method of his differently, making a regretful reference to "how much he had lost"; more than that, he assigns in 1967 the method that he employed for so many years to a "failure of temper".

The fact that Winnicott is ready to open his speech with such an honest and overwhelming statement, seems to be a proof of great intellectual clarity, right? No doubt that Winnicott's words sound like a demonstration of intellectual sincerity; we believe, however, that other things are at stake. And one of the largest evidence comes in the form of the way he closes the lecture, when he says:

I will say only that I do not know if you would like to discuss any of this or if you would rather help me, by writing a letter, to correct me and to meet with the various people around the world who are doing jobs that I didn't mean to steal or just ignore. I don't promise to follow it to the end because I know that I will continue to have ideas that belong to the place where I am at the moment, and I can't help doing it (WINNICOTT, 1967/2007, p. 443).

It causes a certain amazement the discrepancy between the opening and closing of the text - after opening the text in a "regretful criminal" tone, recognizing the cost and lack of ability in the way he worked for years on end, he finishes his speech asking the audience to send suggestions, if they want to, 
but claiming that he is free not to follow them, because the ideas he has will belong to the place where they were born. In other words: he assumes he was wrong and announces that he will go on making mistakes!

In 1945, in the same text where he stated that he "stole" ideas, Winnicott wrote: "listening to what I have to say, and criticizing, you will help me take the next step, which consists of studying the origins of my ideas" (WINNICOTT, $1945 / 2000$, p. 219). We can see that this was a step he hesitated a lot to give and he had great difficulty in doing so; apparently it's up to others, in fact, the "loads of work" needed to articulate his ideas to those of other psychoanalysts, since that " failure of temper" was still present in 1967, and it is relatively safe to say that this "failure", whatever it was, followed him to the end. The "loads of work" needed in order to articulate his thinking with those of other psychoanalysts have been making many psychoanalysts busy (FIGUEIREDO, 2002; OUTEIRAL, 2002; GRAÑA, 2007; BALOCH and ORTEGA, 2007). Anyway it's up to us, heirs to the works and shadows of the great ones that have gone before us, find out what is relevant to organize and systematize under Winnicott's aegis, and what, on the other hand, is seen as an "open work" as a non-dogmatized and non-dogmatizable work.

\section{SCENE 2 - THE STATUTE OF FOLLOWERS}

On 3 June, 1954 Winnicott addressed a long letter to Anna Freud and Melanie Klein (WINNICOTT, 1954/2005, p. 87-90). He was worried: for many years (since 1945) candidates for the British Society of Psychoanalysis had to choose between two lines of qualification: one of them was more focused on Anna Freud's ideas, and the other on the thought of Melanie Klein. With the intervention of some therapists - Winnicott himself included - there was also the possibility of graduating in another line of qualification of the so called Independent Group, which was not affiliated to any of the existing areas. Melanie Klein had been Winnicott's adviser and Joan Riviere (who was openly Kleinian) had been his therapist, and one would imagine him to be understood as "Kleinian" - an understanding that he, however, did not support. In reality, far from that, Winnicott was frankly against the division of the qualifications in groups of filiation and identification, and strongly defended to keep a space for a transparent debate in the Society — with which, he believed, the conditions would be implemented for the scientific maturity and the overcoming of questions and obstacles (denoting someadherence to the widespread empiricist doctrine in England).

He stated in the letter dated 1954: "I consider it to be of absolute vital importance to the future of the Society that both of yourselves shall break up the 
groupings in so far as they are official." (WINNICOTT, 2005, p.89). The maintenance of affiliation groups, he imagined, created inhibited members in their abilities to think due to an excessively dogmatic training - if the applicant opted for a group and for a style of thinking, the "pathways of thought" different from this or that style, would be at first obscure to him. Therefore, the affiliation was harmful because it created imitative and little imaginative analysts.

Winnicott goes further; however; early in the letter he says:

There is a comment that I would like to make at this point which is that there is a slight but interesting difference between the formation of the two groupings. In the case of Mrs. Klein's colleagues and friends it is true, whether by chance or otherwise, that inclusion in the group depends on the fact of having analysis from Mrs. Klein, or an analysand of Mrs. Klein or an analysand of such analysand. [...] In the case of Miss Freud's followers, the matter is more one of a type of education and it happens that this gives a less rigid boundary. One could say that whereas the followers of Mrs. Klein are all children and grandchildren, the followers of Miss Freud all went to the same school. I mention this difference in the formation of the two groups as I think it produces its own complications. (WINNICOTT, 2005, p. 87-88)

More than asserting that the identity affiliation reproduces some embarrassment to the possibilities of the training analyst's thought, therefore, Winnicott suggests (with his usual elusive style) that there are peculiar forms of embarrassment of thought and production of submission according to the figure of affiliation. These "complications" that he refers to focus precisely on the field discussed in this article - when the psychoanalyst "affiliates" he underlies his way of thinking to a "padding point" that would be, precisely, the truth that is assigned to the author of the reference. In this sense Lacanians try to be faithful to the text and to Lacan's "teaching" assuming that by acting like this, they are "thinking well" - and the same happens with Kleinian, Annafreudian or Winnicottian psychoanalysts.

In the context of this problematic, and in the context of this text, we have to ask ourselves: if "Mrs. Klein's followers are all children and grandchildren [and] Miss Freud's followers all went to the same ... school," how to describe Winnicott's followers?

Well, before anything else, we can suggest that these are followers of a leader committed to lose them, like kids playing 'follow the master': followers of a master who move around posts, crawls under the tables and pirouettes so that he won't be followed (although he's probably enjoying the game). 
But I believe that there is a clearer and simple picture to define Winnicott's relationship with his followers. Resuming the game he himself proposes: if Klein's disciples are children and grandchildren of a family and those of Anna Freud went to the same school, we can say that Winnicott's disciples are inspired by the same Protestant leader. The great difficulty here is that the images Winnicott proposed for Klein's and Anna Freud's followers "hook" in a somewhat sarcastic manner in their theorization, and we certainly don't want to suggest that Winnicott gave a religious tone to his theorization (although, considering the religiosity in his more ascetic tints, the proposition is not at all inappropriate).

But, when we think of the bond-like of the Winnicottians to Winnicott, we can roughly establish that they are people who, according to Winnicott, believe in the natural processes of thought, in the value of the game, in creativity; and it is certainly quite paradoxical that people "follow" someone to assert the singularity and the creative thinking.

And yet - this is our hypothesis here - this is not a misunderstanding or a misreading: Winnicott induced to this type of paradoxical submission, to this unusual affiliation. Our argument - which we will still unfold in the following items - is that Winnicott founded a paradoxical doxa (doxa is a path to be followed, according to the classic etymological definition), i.e.: a doxa without dogmatism, a doxa all based on parallel paths or distinguished from the "correct".

The only point that creates suspicion, in this sense, would be that of finding Winnicottians with legislative tendency, arguing about the correct or the orthodox Winnicottism - for orthodoxy means a narrowing in the way that eliminates or constrains the heterodoxies and paradoxes. This constraint seems particularly strange to a consistent reading (and not orthodox) of Winnicott, insofar as, in Winnicott's own words, "if we try to establish strict standards in the present, we will create iconoclastic or claustrophobic people who can't stand the falsity of a rigid system in Psychology more than they can in religion" (WINNICOTT, 2005, p. 88-89).

\section{THE PARADOXICALITY OF THE WINNICOTTIAN DOXA AND ITS IMPLICATIONS Winnicott and the Escherian metapsychology}

Masud Khan tells that one day he went to Winnicott, excited about a book that he wanted him to read, to what Winnicott replied:

"It's no use, Masud, asking me to read anything! If I get tired I fall asleep in the middle of the first page, and if I'm interested I'll start to rewrite it at the end of that [same] first page ". Of course he was making fun of himself, and even more of me, and he really had a talent for it. (KHAN apud NEWMAN, 1995, p. 456). 
Winnicott was clearly a very inventive man; at the same time, this inventiveness seemed to take a certain heartbreaking tone, almost as if he couldn't abide or depend on, as if every moment his thoughts had to be radically his. This image matches the image of the Winnicott that chose to go to medical school so he would never have to depend on a doctor, when he broke his collarbone in adolescence; it matches the Winnicott who slept during the lectures; with the Winnicott almost indifferent to the "world outside" when absorbed in his thoughts. It particularly matches the Winnicottian understanding that intellectuality can function as a defense, and with the Winnicott who had a personal aversion against the erudite intellectualism (CLANCIER and KALMANOVITCH, 1987; PHILLIPS, 19,882,007; KAHR, 1996; RODMAN, 2003; GOLDMAN, 1993a; GOLDMAN, 1993b).

This inventivity taken to the last consequences seems to have a defensive dimension; it reveals, at the same time, the singularity of a thinker capable of inhabiting his own condition and of withdrawing from these significant contributions to a field of shared thinking. Even making things difficult for psychoanalysts due to his inability to borrow or simply to make reference to the ideas of other authors, Winnicott was able to contribute decisively to the shared psychoanalytic thinking. As he escaped from the label of the psychoanalytic intellectual production, Winnicott put in question the role of influence in the creation process in psychoanalysis. Winnicott's positioning, in fact, may represent a renewal regarding the problem faced by psychoanalysis in his time (we have thought of the decades of 50 and 60, particularly) - of the excessive adjustment and the docility of those allowed to call themselves psychoanalysts through the bureaucracy of the institution; in this respect Anna Freud herself made a sarcastic diagnosis:

Self-selection gave place to a thorough examination of the candidates. As a consequence, the exclusion of those who are suspected of mental variations, the eccentric, the self-taught, those with a great imagination; with the advantage of those who, being comfortable and well prepared, work hard enough to strive for greater professional effectiveness (FREUD, Anna apud KUPERMANN, 2008, p. 34).

We believe, therefore, that the psychoanalysis of his time was going through an institutional impasse, resulting in a clinical reflection and also in a significant thought one. Well, the impression that one has, in retrospect, is that Winnicott added an $\mathrm{Escher}^{4}$ tone to the metapsychological building of psychoanalysis, al-

\footnotetext{
${ }^{4}$ M.C. Escher (1898-1972) was a pinter whose most famous works rely on ambiguity, paradox and illusion. His work "Relativity", 1953, is particularly efficient for the image placement that I highlight here.
} 
lowing the transit between authorships and ways of understanding that would be incommunicable, unless Winnicott's incorporated the logic of paradox to psychoanalysis. E aí And then we believe that the defensive dimension of the Winnicottian style led him to create a new world to live: the same Winnicott who had trouble to absorb the Freudian text, who refused formalism, who could not make explicit references to influences in his thinking, favored the creation of a form of movement in psychoanalysis in which the affiliations lose their authoritarian ascendency, in which the separations between the metapsychological buildings are deconstructed with a hint of paradoxicality and surrealism. In that sense it is evident the decisive contribution of Winnicott's style in the configuration of the fields known today as trans-school psychoanalysis (FIGUEIREDO, 2009), of the nomad transfer in psychoanalysis (KUPERMANN, 2008) and of so many other opening and creative thinking movements to contemporary times.

\section{The clownish master and the para-doxa}

It's remarkable, in this context, Winnicott's delay and his apparent reluctance of accepting the fact of being himself, a representative of some kind of orthodoxy (he eventually indicated a correct path, a doxa - even if this doxa was based on paradox ${ }^{5}$ ). The status that this doxa assumes in the winnicottian legacy still retains its peculiarities, and for a number of reasons: one we can consider rhetorical, one we can consider political and a third one we can consider ethical.

-What we call rhetorical, the most apparent among them, derives from Winnicott's posture of criticizing and refusing, during most of his life, so that the position of a leader, with the marking of the Winnicottian doxa as territory becomes the focus of a controversy. From there we can understand the particularities of transfers to Winnicott, quite distinct from each other and even pointing to radically different clinical styles. The point is that Winnicott did not occupy the place of a charismatic leader long enough to organize a Winnicottian movement, as was the case with so many "isms" in psychoanalysis. This aspect is decisive, we believe, for so many different things occur under the curious distinction of "Winnicottism".

- In the political dimension, embedded in the context of the psychoanalytic institution, this Winnicottian ethics played a central role, since the standardization of formation and the rigidity of the transfers and of the games of power imposed at that time, formed a deadlock and a disservice to psychoanalytic thinking - the stylistic subversion proposed by Winnicott seems to have fa-

\footnotetext{
${ }^{5}$ Winnicott is particularly clear as to the nature and role of doxa which he proposes in the introduction to Playing and Reality (WINNICOTT 1971/2010).
} 
vored, somehow, the revitalization of the processes of creative thinking among the members and the institution itself in a broader sense.

- The third dimension, as we said, seems to be of ethical character. The way Winnicott authorizes himself is peculiar above all because it could not stop being; how he settled as an author, his idiosyncrasies and style, even the prosody of his texts, all this contributes notably to establish the problematic that he mobilizes; we use the term "ethics" here, so as to connote "shelter", "an installation of yourself". In this sense we can say without fear that Winnicott was a great author - as he introduces his theoretical contributions, from the point of view of style, in a strongly favorable environment to its full development. That is, Winnicott may not have been a great rhetorical, but he was a great author.

According to this point of view, if we consider Winnicott's relationship with his psychoanalyst colleagues, we can understand one of the reasons why his works had so much impact in the psychoanalytical environment ${ }^{6}$ : they invite us to an exercise of thinking that demands the reader to work-unlike so many texts written just to praise the author, leaving the reader to the bland work of imagining how these truths-in-itself ${ }^{7}$ were produced inside the author. At the same time we consider that this form of production and theorization elaborated in Winnicott's works are still updated as they invite us, even today, to rethink thesubmission, the games of power and unquestioned submission to dogmatism that permeate (since ever) the production in psychoanalysis.

\section{ONE LAST SCENE - FINAL CONSIDERATIONS}

Marion Milner tells that once Winnicott opened a class saying to his students: "whatever you take from me, you will have to withdraw from chaos" (GOLDMAN, 1993a, p. 117). It's a curious statement, given that teachers in general consider that one of their tasks is to make their communications understandable - but his words are consistent with Winnicott's stylistic position. In Communicating and not communicating, for example, he says that "he will allow himself considerable freedom to follow his theme wherever it takes him" (WINNICOTT, 1962, in GOLDMAN, 1993a, p. 25). Other examples of his behavior have already been mentioned in previous items of this text. The question is: what kind of consequences this resolution of his imposes to the legacy that he leaves for this

\footnotetext{
${ }^{6}$ I think it is clear that there are other good reasons for the impacto f his work, as for example, the relevance of his conceptual proposition, his eloquence and rethoric, his clinical geniality, etc.

${ }^{7} \mathrm{~A}$ good discussion about the costs of an excessive narcisinm process of the writing appears in What's true and whose idea was it?, by psychoanalyst Thomas Ogden (OGDEN, 2010).
} 
area of study - will those influenced by Winnicott have now or in the future the same freedom using the ideas he raised for himself?

The style of Winnicott shows a strong association with his psychoanalytic propositions, as Ogden thoroughly demonstrates (OGDEN, 2001) and gathers important issues for psychoanalysis. Between the "spontaneous" style and the "narcissist" style, between the "founder of paradigm" and the "renewer of psychoanalytic thought", in summary: between hagiography and refusal, there rests a work with a disturbing power worthy of attention. Perhaps one of the affinities between Winnicott's and Nietzsche's thinking, suggested by Adam Phillips (PHILLIPS, 1988/2007, p. $x$ ) is that interruption of the debt ethics within the psychoanalytic institution. If psychoanalysis suffered, at the time of Winnicott's intellectual maturity, with the docility of the candidates and members and with the normalization of belongings, Winnicott proposes a model of thought in which the responsibility upon yourself is transferred to the reader or the apprentice or the candidate to psychoanalyst, until the last consequences; Winnicott's current reading has a lot to gain if the less "cute", more corrosive and tense aspect of his propositions could be recognized: just like he used to steal shamelessly, he also defended the value of the aggression, fought the idea of death drive and criticized, whenever he had a chance, the orthodoxy and idolatry. In line with his theorizations about child delinquency (WINNICOTT, 1984/2005), Winnicott assumes it as possible and supports as a health movement when someone can steal something and declare it, as if stealing was a right while there was responsibility for it; in another category, but within the same problematic, Winnicott's propositions regarding the primacy of the Oedipus complex and the centrality of the paternal role in the subjective configuration allows the relationship to debt and the relationship to autonomy to be put in new categories. In short: Winnicott cannot be the object of an exclusive study by the doctors inspired by Winnicott.

During the height of Winnicott's anguish authorization ${ }^{8}$ (between 1935 and 1945, roughly), psychoanalysis was in deep crisis. In France, the figure of Freud was dissipating against a withering psychoanalysis and, just like a prophet, Lacan proposed the "return to Freud". In England, the figure of Freud was in the center of disagreements, especially with the arrival of Freud's family in London; Anna Freud occupied the place of rightful heiress of the Freudian legitimacy, having to face in London challenges from a strong, well supported Melanie

\footnotetext{
"I borrow the phrase "anguish of authorization" from the discussions led by Harold Bloom about the anxiety of influence in the process of authorization (BLOOM, 2002). For further information about the anxiety of influence and authorization in psychoanalysis, I refer the reader to my Master's dissertation (FRANCO, 2012) and to the article by Ronald Britton in this regard (BRITTON, 2003).
} 
Klein who was also a contester of this supposed "Freudian legitimacy" (KING and STEINER, 1998). Summarizing, the phratry fiercely disputed the right to speak on behalf of the totemic leader, and Winnicott occupied a very delicate and paradoxical place in this mess.

And what about us today? We have to look forward to the challenge of addressing without compromise all the ambiguity and complexity of his authorization, in his assumption of influence in the British context, in that his process underwent appeasement, a non-violent revolution, of iconoclasm and - why not? - a return to Freud. If Winnicott's work is central in the theoretical design that is the foundation of the "contemporary psychoanalysis" (FIGUEIREDO, 2009), we still have: 1 . The challenge of making Winnicott's reading texts contemporary, of making Winnicott a vector and a catalyst for thinking about contemporary challenges to the world in general, to the clinic and - especially - to psychoanalysis and 2. Actively avoid the Winnicottian circumscription to groups, sects and identity organizations of idolatry and recognition.

Winnicott says, in his text "The use of an object", that the developing subject should be able to destroy an object that resists its destruction, that is there (on the other side) to receive him; for Winnicott, this destructive use of a libidinal object is a necessary step of the subjective constitution and of the emotional maturity (WINNICOTT, 19692010). Well, in this same way of thought, we believe it's necessary to destroy Winnicott, Klein, Lacan and even Freud — to meet them again on the other side, without a shadow of a doubt.

Recebido/Received: 9/2/2014. Aprovado/Accepted: 6/12/2014.

\section{REFERENCES}

BEZERRA, B. e ORTEGA, F. (orgs) (2007) Winnicott e seus interlocutores. Rio de Janeiro: Relume Dumará.

BLOOM, H. (1973/2002). Angústia de influência: uma teoria da poesia. Rio de Janeiro: Imago.

BRITTON, R (2003). Ansiedade de publicação. In: Crença e imaginação. Rio de Janeiro: Imago.

CLANCIER, A; KALMANOVITCH, J. (1987). Winnicott and paradox: from birth to creation. New York: Tavistock Publications.

FIGUEIREDO, LC (2002). A tradição ferencziana de Winnicott — apontamentos sobre regressão e regressão terapêutica, in: Revista Brasileira de Psicanálise, São Paulo, v. 36, n. 4, p. 909-928.

FIGUEIREDO, LC (2009). As diversas faces do cuidar: novos ensaios de psicanálise contemporânea. São Paulo: Escuta.

FRANCO, W (2012). Autorização e angústia de influência em Winnicott. Dissertação de mestrado (Instituto de Psicologia da Universidade de São Paulo) apresentada em 2012. São Paulo. 
GOLDMAN, D (1993a). Introduction. In: (Ed.). In one's bones: the clinical genius of Winnicott. Pennsylvania: Jason Aronson.

GOLDMAN, D. (1993b). In search of the real: the origins and originality of D. W. Winnicott. Pennsylvania: Jason Aronson.

GRAÑA, R (2007) Origens de Winnicott: ascendentes psicanalíticos e filosóficos de um pensamento original. São Paulo: Casa do Psicólogo. (1993b). In search of the real: the origins and originality of D. W. Winnicott. Pennsylvania: Jason Aronson.

KAHR, B (1996). Winnicott: a biographical portrait. Madison: International Universities Press.

KING, P; STEINER, R (Orgs.). (1998). As controvérsias Freud-Klein 1941-1945. Rio de Janeiro: Imago.

KUPERMANN, D (2008). Presença sensível: cuidado e criação na clínica psicanalítica. Rio de Janeiro: Civilização Brasileira.

NEWMAN, A. (1995) Non-compliance in Winnicott's words: a companion to the work of D.W.Winnicott. New York: New York University Press.

OGDEN, T (2010). O que é verdadeiro e de quem foi a ideia?, in: : Esta arte da psicanálise: sonhando sonhos não sonhados e gritos interrompidos. Porto Alegre: Artmed.

OGDEN, T. (2001). Lendo Winnicott. Revista Brasileira de Psicanálise, São Paulo, v. 36, n. 4 , p. $737-756$.

PHILLIPS, A (1988/2007). Winnicott. Londres: Penguin.

RODMAN, R (2003). Winnicott: life and work. Cambridge: Da Capo Press. WINNICOTT, DW. (1945/2000). Desenvolvimento emocional primitivo. In: . Da pediatria à psicanálise. Rio de Janeiro: Imago.

WINNICOTT, DW (1962/1993).Communicating and not communication leading to the study of certain opposites, in: GOLDMAN, Dodi: In one's bones: the clinical genius of Winnicott. Pennsylvania: Jason Aronson.

WINNICOTT, DW. (1967/2007). DWW sobre DWW. In: WINNICOTT, Clare; SHEPHERD, Ray; DAVIS, Madeleine (Orgs.). Explorações psicanalíticas. Porto Alegre: Artmed.

WINNICOTT, DW. (1969/2010) - The use of na object and relating through identifications, in: WINNICOTT, DW: Playing and reality. Abingdon: Routledge Classics.

WINNICOTT, DW. (1984/2005). Privação e delinquência. São Paulo, Martins Fontes.

WINNICOTT, DW. (1971/2010). Playing and reality. Abingdon: Routledge Classics.

Wilson de Albuquerque Cavalcanti Franco wilsondeacfranco@gmail.com

Luís Cláudio Figueiredo

Iclaudio@netpoint.com.br

Traduzido do português por Doris Dana/translated from portuguese by Doris Dana

dorisdana@uol.com.br 
